\title{
Study on School-Enterprise Collaborative Education Mechanism Based on Apprenticeship Practice
}

\author{
Jukang Liu ${ }^{1, *}$ \\ ${ }^{1}$ School of Information Qingdao Technical College, Qingdao, Shandong, 266555, China \\ *Corresponding author. Email: 275233128@qq.com
}

\begin{abstract}
At present, China has ushered into a new stage in terms of its development. With the proposal of Made in China 2025, industrial upgrading and economic restructuring are accelerating. Thus, it is urgent demand for higher technical personnel. Compared with developed countries, China's vocational education system construction is not perfect enough, so does for the system standard, and enterprises lack of motivation to participate in school-running. "The Implementation Plan of National Vocational Education Reform" puts forward the future direction for vocational education, highlighting the important position and role of vocational education. The apprenticeship class of computerized numerical control technology major is jointly set up by the school that the author works and Qingdao Ming Haoyuan Precision Machinery Co., Ltd. In the process of practice, a series of appropriate ways to collaborate cultivate students by schools and enterprises are explored, which matches the specialty setting and enterprise needs, curriculum content and professional standards, teaching process and production process, scientific research process and skills competition.
\end{abstract} Keywords: Collaborative Education; Apprenticeship; Credit Transfer; Teacher Construction

\section{INTRODUCTION}

The construction of school-enterprise collaborative education mechanism is based on the concept of entirety and connection. Collaborative education is to integrate all available resources and give full play to the subjective initiative of each subject, so as to maximize the benefits and ensure the lowest risk rate. Collaborative education requires the government to coordinate all parties to establish corresponding policies and regulations system, so as to ensure the benefit sharing of all parties; at the same time, they need to take certain risks, and promote the parties involved in "production, learning, competition, research, innovation" to actively play their respective advantages. The establishment of collaborative education mechanism with enterprises is a new requirement for vocational colleges to effectively improve their education ability. From the resource investment to the present connotation improvement, vocational education reform has entered a new era. The gathering of shared-interest communities and the overall performance of colleges, banks and enterprises are the new path to improve the education ability of vocational colleges.

Haier College of Qingdao Technical College cooperates with Qingdao Ming Haoyuan Precision Machinery Co., Ltd. to carry out the modern apprenticeship system in the computerized numerical control technology specialty on a pilot basis, explore a set of collaborative system in the school-enterprise collaborative education mechanism, and realize the efficient training method for high-tech skilled talents. Schools and enterprises jointly set up a group which integrates industry and teaching for modern apprenticeship to complete the specific work of "double subject" education. The main responsibilities of schools and enterprises in personnel training should be clarified. Both schools and enterprises are responsible for organizing the formulation of modern apprenticeship personnel training plan, apprenticeship management and assessment; The enterprise is responsible for providing students with apprenticeship positions and internship training opportunities, and selecting excellent technical personnel as masters to guide apprentices to study the actual production courses of the enterprise. During the learning period, the apprentice needs to complete the corresponding training content according to the learning plan formulated by the enterprise master according to the actual production of the workshop. After the apprentice has completed all the courses, the enterprise and the school jointly assess the apprentice, The scores in the enterprise and in the school account for $50 \%$, respectively. schools and enterprises jointly cultivate talents, formulate talent training programs, and are responsible for curriculum system development, curriculum construction, teaching staff construction, practical teaching conditions construction, teaching operation and monitoring.

\section{EXPLORING TO ESTABLISH CREDIT MUTUAL RECOGNITION SYSTEM BETWEEN SCHOOLS AND ENTERPRISES}

This people-oriented principle has been put in the first place. We actively respond to the national policy of 
teaching students in accordance with their aptitude. Aiming at the school apprenticeship system, credit exchange methods with clear exchange standards has been formulated so as to solve the problem of classroom credit and practice credit exchange and many asymmetric points in the process of school apprenticeship training such as work and study alternation, flexible class hours, and credit asymmetry caused by enterprise practice training. The final scores of students are jointly recognized by the school and the enterprise. The exchange and mutual recognition policy is implemented in the classroom credits and practice credits. The relevant implementation measures are formulated, and the exchange standards and curriculum exchange conditions for classroom credits and practice credits are clarified, so as to ensure the credit mutual recognition of students (apprentices) in school and enterprise learning. There is no credit exchange and mutual recognition in the public curriculum system; If the professional basic courses are highly related to the enterprises, the enterprises can discuss with teaching and research department about credit exchange and mutual recognition; The credit exchange can be implemented in the core courses of computerized numerical control technology specialty. The exchange credits for the expanded courses of computerized numerical control technology cannot exceed half of the total credits, and so on. The implementation of these measures has greatly promoted the enthusiasm of students in the apprenticeship class to learn knowledge and skills

\section{PERFECTING THE SYSTEM AND STANDARD OF DOUBLE SUBJECT PERSONNEL TRAINING}

In the process of implementing the apprenticeship system, a new talent training mode is proposed, which is the result of the joint efforts of both the school and the enterprise. According to the growth law of professional technical talents and the relevant post standards of computerized numerical control technology, the talent training mode featured by its "rotation between engineering and learning, on-the-job training, combination of education and training, of competition and training and innovation and research " is constructed to train apprentice's professional technical ability in a staged manner. Students learn general courses, professional basic theory courses in class, and practice courses in practical posts. They will be jointly guided by the professional teachers from schools and tutors from enterprises to complete technical skills training and become a useful person in their work. In the process of cultivating talents, we should always follow the spirit of craftsman, and let students (apprentices) have "skills" and "virtues". By relying on skills competition, enterprises can understand the difference between the requirements of skills competition and actual processing and production and drive the enterprise tutors to guide competitions and even participate in competitions themselves, so that the teachers of enterprises are closer to school. Meanwhile, in the process of the guidance of the skills competition, teachers and enterprise tutors can learn from each other, thus achieving the purpose of common promotion. In the process of training, students should actively participate in the innovation and patent research and development of enterprises. Thus, they can have a broader vision and have a higher level in their future career. Table 1 lists the awardwinning and participating patent data of apprenticeship members in recent years.

Table 1. Awards and patents of apprenticeship students

\begin{tabular}{|c|c|c|c|c|}
\hline \multicolumn{5}{|c|}{ Award winning and patent participation of apprenticeship members } \\
\hline $\begin{array}{c}\text { Number of } \\
\text { sessions }\end{array}$ & $\begin{array}{c}\text { Number of } \\
\text { winners }\end{array}$ & $\begin{array}{c}\text { Number of } \\
\text { awards }\end{array}$ & $\begin{array}{c}\text { Number of } \\
\text { enterprises } \\
\text { participating }\end{array}$ & $\begin{array}{c}\text { Number of } \\
\text { participating } \\
\text { patents }\end{array}$ \\
\hline 2016 & $\mathbf{6}$ & $\mathbf{8}$ & $\mathbf{8}$ & $\mathbf{1}$ \\
\hline 2017 & $\mathbf{7}$ & $\mathbf{1 2}$ & $\mathbf{1 2}$ & $\mathbf{4}$ \\
\hline 2018 & $\mathbf{1 1}$ & $\mathbf{2 3}$ & $\mathbf{2 3}$ & $\mathbf{1}$ \\
\hline 2019 & $\mathbf{1 2}$ & $\mathbf{1 7}$ & $\mathbf{1 7}$ & $\mathbf{2}$ \\
\hline
\end{tabular}

In addition, the standards used in personnel training are extracted by the professional teachers and tutors of the enterprise from the knowledge, skills and quality elements required in the process of processing typical workpieces. The skills required by enterprises are integrated into curriculum planning and design. In addition, we need to match curriculum content with professional standards and posts, learning content with actual work, school curriculum with enterprise courses in order to construct a curriculum system of education and training based on the production process of typical products of enterprises. Moreover, the specialty should be matched with enterprises' demand, curriculum content should match with NC processing post standard, so does for teaching process and production process, scientific research process and skills competition. 


\section{ESTABLISHING A TEACHING TEAM WHO ARE SHARED AND EMPLOYED BOTH BY ENTERPRISES AND SCHOOLS}

According to the talent training plan and apprentice post requirements, the school and enterprise jointly discussed and formulated a series of documents on the management methods of modern apprenticeship "double tutors" and the requirements for teachers to participate in the enterprise research and training in the front line of the enterprise. The technical requirements and selection standards of "double tutors" are described in detail; First, the responsibilities of the dual tutors are clearly defined; Secondly, the incentive and corresponding restraint mechanism are established. Finally, the ways to select double tutors is clarified. Selection of enterprise tutors: excellent technical talents from cooperative enterprises are selected. They will be given certain teaching subsidies and will be assessed the teaching tasks undertaken by the tutors; Selection of school tutors: excellent teachers with double certificates from the school are selected, and they will cooperate with the enterprises' tutors to provide corresponding guidance to students in the field of apprenticeship. The practice in enterprises and technical service of teachers are the important basis for promoting professional and technical posts. A flexible mechanism for the mobility of talents has been established. In addition, both school and enterprise jointly formulate incentive system and assessment reward and punishment system for those who are in a temporary post for personal training and development, take part in horizontal joint technology research and development and participate in professional construction. The channels of mutual employment and sharing of dual tutors are available and the mechanism is flexible, which fully mobilizes the enthusiasm of teachers and enterprises' tutors.

At the same time, our college actively advocates teachers to study and train in enterprises which is mainly divided into long-term continuous research and short-term continuous research. As an old say goes "it is never too late to learn". Teachers can use summer semester (summer vacation time) and winter semester (winter vacation time) to go to production line of cooperative enterprises. There is no heavy teaching task during this period, so that teachers can really focuse on the latest development direction of the industry and understand the trend of technology. Through enterprise research, the practical ability of college teachers has been greatly improved, and the vision is also expanded, and better service and teaching are provided, thus building a team of double-qualified teachers with high level, high technology and excellent skills.

\section{EXISTING PROBLEMS}

There are many problems in the production and application of new things. In the process of operation, we also find some problems: (1) it is difficult for enterprise tutors to be school-based, and t for teachers to be enterprise-based. The cooperation between school and enterprise needs to be further strengthened. In the actual teaching, because most tutors of enterprises get their skills from practice, that is, the "practical school", and each teacher has their own way to solve problems, thus the individual differences are relatively large; Most of the school tutors have rich professional knowledge and strong language skills, belonging to the "academic school". But most of them do not have experience in real enterprises, so they are not closely related to their posts. Most of the enterprise tutors are the technical backbone of the enterprise, having their own fixed jobs, and the production task is relatively heavy, so it is difficult to find more time to communicate with teachers for a long time. For teachers, the daily teaching task is heavy, and it is difficult to go deep into the front line of the enterprise. (2) The unstable mind of students. Most of the students have not experienced the real enterprise environment, so when they really work in enterprises, they will find that there is a big gap between the job and their ideals and beliefs, and they can not correctly position themselves. So, some students will beat a retreat.

In this regard, we actively find solutions: (1) If teachers participate in the real production link in enterprises, it will bring economic benefits to the enterprise. The enterprise can give teachers certain labor remuneration according to their work output, so that teachers can get experience and certain labor remuneration. At the same time, we should strengthen the language expression ability of enterprise tutors in order to invite them to give lectures at school; When they are invited to participate in the course development and assistance in teaching, they will be given a certain amount of labor remuneration. (2) In the view of the problems in students, we usually give students a onemonth adaptation period. After one month, for all the students who decide to continue to work in enterprises, enterprises will also have certain assessment options for students according to their ability, and choose the suitable training methods for students.

\section{FUTURE DEVELOPMENT DIRECTION}

(1) We need to discuss with the government and enterprises to establish Industry Vocational Education Steering Committee with three parties involved to lay a solid management foundation for school-enterprise collaborative education. The market demand is the one which gives out the question booklet, the school is a test taker, the enterprise is the examiner, and the student is the beneficiary. This requires the committee to play an active role, especially the leading role of the government. More enterprises should be selected that care about education and can contribute to education. More students benefit from active participation. Of course, enterprises also need to survive and develop, so enterprises can not be the giver all the time, which requires the government to introduce relevant policies to ensure the efficiency of enterprises, so that the enthusiasm of enterprises will be higher. At the same time, the school should also actively cultivate more 
students who can create value for the enterprise, so as to form a virtuous circle and satisfy the three parties.

(2) Combined with the actual production knowledge needs of enterprises, the professional teaching and curriculum standards are developed, and the personnel training program is adjusted accordingly. The answer is obvious: the development and design of teaching standards for professional talent training program. Professional teaching standards should play a strategic role because it should not only guide the formulation and adjustment of professional curriculum standards, the construction and integration of professional teaching resources, but also the optimization and upgrading of professional training conditions, and the formation of professional teaching team and the implementation and supervision of professional teaching evaluation. The enterprise-based teaching standard can better promote the operation of the modern apprenticeship in the school, which can make the textbook content orient toward enterprise, and facilitate to compile the loose-leaf textbook suitable for the apprenticeship learning in the school.

\section{CONCLUSION}

From the appearance of vocational and technical universities in recent years, the state attaches great importance to high-tech skilled talents. Therefore, we focus on all available resources and actively promote schoolenterprise collaborative education in computerized numerical control technology specialty. But this process is doomed to be difficult, and may also be long-term. Only with continuous improvement, continuous improvement, and standardization in the specific practice can we move towards a better tomorrow and develop China's vocational education.

\section{REFERENCES}

[1] Jiankang Dong, Yan Han. Roles and positioning of various subjects in collaborative innovation system [J]. Science and technology of Chinese universities, 2013(6): $52-54$

[2] Xiaoming Huang, Xiaochun Yang, Ming Zhou, et al. Practical research on modern apprenticeship training mode of automobile repair major-Taking the pilot project of Yunnan Institute of mechanical and electrical technology as an example [J]. Times automotive, 2019(10): 67-72

[3] Yang Chengliang. Research on the construction of talent training mode integrating industry and Education -- Taking the pilot of modern apprenticeship in chain operation management as an example [J]. Rural economy and science and technology, 2017 (24): 261263

[4] Weihua Kuang, Guobin Li, Yonghua Sheng. Research and practice of modern apprenticeship specialty based on the integration of industry and education [J]. Journal of Jincheng Polytechnic, 2020 (7)

[5] Xinming Wang. Several problems and suggestions for the full implementation of modern apprenticeship in China [J]. China Vocational and technical education, 2020 (33): 30-33

[6] Hong Zhang. Research and implementation of modern apprenticeship talent co-education mechanism under the background of industry education integration [J]. Education Science Forum, 2020 (08): 45-4 